\title{
PEMBUATAN SEL FOTOVOLTAIK PASANGAN CuO/Cu DAN CUO/STAINLESS STEEL DALAM BENTUK TUNGGAL DAN SERABUT MELALUI METODA PERENDAMAN DENGAN NaOH
}

\author{
Olly Norita Tetra, Admin Alif, Febrianki Ultari \\ Laboratorium Foto/Elektrokimia, Jurusan Kimia, FMIPA, \\ Universitas Andalas - Padang \\ Email: olly512@yahoo.com
}

\begin{abstract}
The research about Photovoltaic cell of $\mathrm{CuO} / \mathrm{Cu}$ and $\mathrm{CuO} /$ Stainless steel in single and fiber made by $\mathrm{NaOH}$ submersion method by using $\mathrm{KCl}$ electrolyte has been done. In this research, the $\mathrm{KCl}$ solution is used with different concentrations. The measurement of intensity and voltage is done before and after the Photovoltage cell is radiated by the sun light for approximately 5 minutes. The optimum concentration obtained is $0,3 \mathrm{M}$. The highest value for intensity and voltage is obtained on fiber $\mathrm{CuO} / \mathrm{Cu}$ electrodes with the values are $0,364 \mathrm{~mA}$ and $0,170 \mathrm{~V}$, measured at $11.00-12.00$ in the noon. The length time of submersion of $\mathrm{Cu}$ electrode with $\mathrm{NaOH}$ to is affecting the intensity and voltage of $\mathrm{CuO}$ production, submerging in relatively optimal in 24 hour. The Photovoltaic cell can be used with or without the sun light, with the voltage being produced is 0,109 $\mathrm{mA}$ for fiber $\mathrm{CuO} / \mathrm{Cu}$ electrodes. $\mathrm{CuO} / \mathrm{Cu}$ electrodes and Stainless steel $\mathrm{CuO} / \mathrm{Cu}$ electrodes can be used on Photovoltaic cell.
\end{abstract}

Keywords : Photovoltaic cell, electrode, intensity, voltage

\section{PENDAHULUAN}

Sel Fotovoltaik (PV) adalah alat yang mengkonversi sinar matahari menjadi listrik, melewati siklus termodinamika dan generator mekanis. Komponen utama sistem surya fotovoltaik adalah modul yang merupakan unit rakitan beberapa sel surya fotovoltaik.

Teknologi pembuatan sel surya dengan bahan silikon dan polikristal secara teoritis sudah pernah dibuat. Teknologi ini cukup canggih dan keuntungannya adalah harganya yang murah, bersih, mudah dipasang serta dioperasikan dan mudah dirawat. Sedangkan kendala utama yang dihadapi dalam pengembangan energi surya fotovoltaik adalah investasi awal yang besar dan harga per kWh listrik yang dibangkitkan relatif tinggi, karena memerlukan subsistem yang terdiri atas baterai, unit pengatur dan inverter sesuai dengan kebutuhannya. ${ }^{[1]}$

Sel fotovoltaik yang sering dibicarakan adalah fotovoltaik padat namun dalam penelitian ini akan digunakan sel fotovoltaik cair. ${ }^{[2,3,4]}$ Sel fotovoltaik cair pada dasarnya menggunakan prinsip sel galvani, pada penelitian ini dicoba menggunakan sel surya untuk mengeksitasi elektron dari pasangan elektroda dalam larutan elektrolit.

Elektroda $\mathrm{CuO} / \mathrm{Cu}$ merupakan pasangan elektroda yang memiliki bandgap 1,9-1,3 eV. Jika bandgap tersebut dikonversikan ke bentuk panjang gelombang, maka nilainya menjadi $610-892$ $\mathrm{nm}$. Hal ini menunjukkan bahwa pasangan elektroda ini dapat menyerap energi foton dari cahaya matahari pada range cahaya tampak (visible) dan infra merah (IR). ${ }^{[5,6]}$

Pada penelitian pendahuluan, ditemukan bahwa dengan meningkatnya konsentrasi elektrolit, maka besar tegangan dan kuat arus yang dihasilkan juga meningkat dan dengan menggunakan elektrolit $\mathrm{NaCl}$ dan $\mathrm{NaOH}$ terdapat kendala pada konsentrasi elektrolit yang besar, dimana pada elektroda $\mathrm{Cu}$ yang menggunakan $\mathrm{Cu}$ serabut akan cepat teroksidasi. ${ }^{[7]}$ Oleh sebab itu pada penelitian ini akan dibuat fotovoltaik dengan elektrolit $\mathrm{KCl}$ dan beberapa pasangan elektrodanya $(\mathrm{CuO} / \mathrm{Cu}$, $\mathrm{CuO}$ /Stainless Steel, dan $\mathrm{Cu}$ serabut dan tunggal). Dari beberapa pasangan elektroda tersebut dipelajari apakah elektroda pasangan $\mathrm{CuO} / \mathrm{Cu}$ dan $\mathrm{CuO}$ /Stainless Steel dalam bentuk tunggal dan 
serabut dapat digunakan sebagai sel fotovoltaik cair dalam larutan elektrolit KCl. Pengaruh lama waktu perendaman $\mathrm{Cu}$ untuk membuat $\mathrm{CuO}$ dengan $\mathrm{NaOH}$ terhadap kuat arus dan voltase yang dihasilkan dan pengaruh konsentrasi larutan elektrolit $\mathrm{KCl}$ terhadap kestabilan elektroda pasangan $\mathrm{CuO} / \mathrm{Cu}$ dan $\mathrm{CuO} /$ Stainless Steel dalam sel fotovoltaik cair juga dipelajari.

\section{METODE PENELITIAN}

\section{Alat dan Bahan}

Alat- alat yang digunakan yaitu neraca analitis, alat-alat gelas, multitester, dan rakitan sel surya. Bahan yang digunakan yaitu $\mathrm{KCl}, \mathrm{NaOH}$, dan aquabides.

\section{Prosedur Kerja}

\section{Penyiapan elektroda}

Pembuatan elektroda $\mathrm{Cu}$ tunggal dan serabut berasal dari kabel standar PLN yang berisi kawat $\mathrm{Cu}$ dan dipotong sepanjang $\pm 25 \mathrm{~cm}$. Karet pembungkus kabel $\mathrm{Cu}$ dilepaskan, dan disisakan karet pembungkus tersebut sepanjang $\pm 4 \mathrm{~cm}$.

Elektroda $\mathrm{CuO}$ dibuat dengan cara mengoksidasi kawat $\mathrm{Cu}$ dengan menggunakan larutan $\mathrm{NaOH}$ 0,5 N. Masing-masing elektroda $\mathrm{CuO} / \mathrm{Cu}$ tunggal dan serabut yang sudah teroksidasi kemudian dipasang ke dalam tabung reaksi yang sudah dilubangi pada bagian bawahnya.

\section{Penentuan konsentrasi optimum elektrolit $\mathrm{KCl}$ dengan menggunakan pasangan elektroda $\mathrm{CuO} / \mathrm{Cu}$ tunggal}

Dituangkan larutan $\mathrm{KCl} 0,5 ; 0,4 ; 0,3 ; 0,2 ; 0,1 \mathrm{M}$ ke dalam masing-masing gelas wadah unit sel sebanyak $250 \mathrm{~mL}$. Pasangan Elektroda $\mathrm{CuO} / \mathrm{Cu}$ tunggal dimasukkan ke dalam masing-masing gelas larutan yang konsentrasinya berbeda-beda tersebut. Larutan dan elektroda disinari dengan cahaya matahari selama \pm 5 menit dimulai dari konsentrasi yang rendah ke konsentrasi yang tinggi. Kemudian larutan tersebut diukur arus dan voltasenya. Hal yang sama dilakukan dengan mengganti pasangan elektroda $\mathrm{CuO} / \mathrm{Cu}$ serabut, pasangan elektroda $\mathrm{CuO}$ tunggal /Stainless Steel, pasangan elektroda $\mathrm{CuO}$ serabut/Stainless Steel.

\section{Penentuan arus dan voltase dari sel fotovoltaik pasangan elektroda $\mathrm{CuO} / \mathrm{Cu}$ tunggal dengan} variasi waktu penyinaran

Larutan $\mathrm{KCl}$ dengan konsentrasi yang didapatkan pada kondisi optimum sebelumnya dituangkan ke dalam gelas wadah unit sel. Setelah masing-masing wadah unit sel dan tabung elektroda $\mathrm{CuO} / \mathrm{Cu}$ tunggal diisi dengan larutan $\mathrm{KCl}$, maka lakukan pengukuran arus dan voltase. Pengukuran ini dilakukan sebelum penyinaran dengan sinar matahari (di dalam ruangan). Setelah itu, larutan tersebut disinari dengan sinar matahari selama \pm 5 menit. Arus dan voltase kemudian diukur dari masing-masing larutan. Selanjutnya pengukuran dilanjutkan dengan selang waktu 60 menit yaitu dari pukul 10.00 sampai 14.00 WIB.

Hal yang sama dilakukan dengan mengganti pasangan elektroda $\mathrm{CuO} / \mathrm{Cu}$ serabut, pasangan elektroda $\mathrm{CuO}$ tunggal /Stainless Steel, pasangan elektroda CuO serabut /Stainless Steel.

Penentuan arus dan voltase dari sel fotovoltaik pasangan elektroda $\mathrm{CuO} / \mathrm{Cu}$ dan $\mathrm{CuO}$ /Stainless Steel dalam bentuk tunggal dengan elektrolit KCl dengan memvariasikan lama waktu perendaman $\mathrm{Cu}$ dengan $\mathrm{NaOH}$

Larutan $\mathrm{KCl}$ dengan konsentrasi optimum dituangkan ke dalam gelas wadah unit sel kemudian celupkan elektroda $\mathrm{CuO}$ tunggal / $\mathrm{Cu}$ tunggal dan $\mathrm{CuO}$ tunggal / Stainless Steel dan lakukan pengukuran arus dan voltase masing-masing larutan. Pengukuran ini dilakukan sebelum 
penyinaran dengan sinar matahari (di dalam ruangan). Setelah itu, larutan tersebut disinari dengan sinar matahari \pm 5 menit. Arus dan voltase kemudian diukur dari masing-masing larutan.

Penentuan arus dan voltase dari sel fotovoltaik pasangan elektroda $\mathrm{CuO} / \mathrm{Cu}$ dan $\mathrm{CuO}$ /Stainless Steel dalam bentuk tunggal dan serabut dengan elektrolit KCl tanpa disinari cahaya matahari

Larutan $\mathrm{KCl}$ dengan konsentrasi optimum dituangkan ke dalam gelas wadah unit sel kemudian celupkan elektroda $\mathrm{CuO} / \mathrm{Cu}$ dan $\mathrm{CuO} /$ Stainless Steel (dalam bentuk serabut dan tunggal). Kemudian dilakukan pengukuran arus dan voltase masing-masing larutan. Pengukuran ini dilakukan tanpa penyinaran dengan sinar matahari (di dalam ruangan gelap pada malam hari).

\section{HASIL DAN PEMBAHASAN}

Pengaruh Lama Waktu Perendaman Cu dengan NaOH Untuk Pembuatan Elektroda CuO Terhadap Kuat Arus dan Voltase Sel Fotovoltaik

Variasi waktu perendaman $\mathrm{Cu}$ dengan $\mathrm{NaOH}$ 0,5 $\mathrm{N}$ mempengaruhi kuat arus dan voltase yang dihasilkan. Hasil ini menunjukkan bahwa kuat arus dan voltase yang dihasilkan pada saat disinari lebih besar dari pada sebelum disinari dengan kondisi optimum perendaman $\mathrm{Cu}$ dengan $\mathrm{NaOH}$ adalah 24 jam (Gambar1).

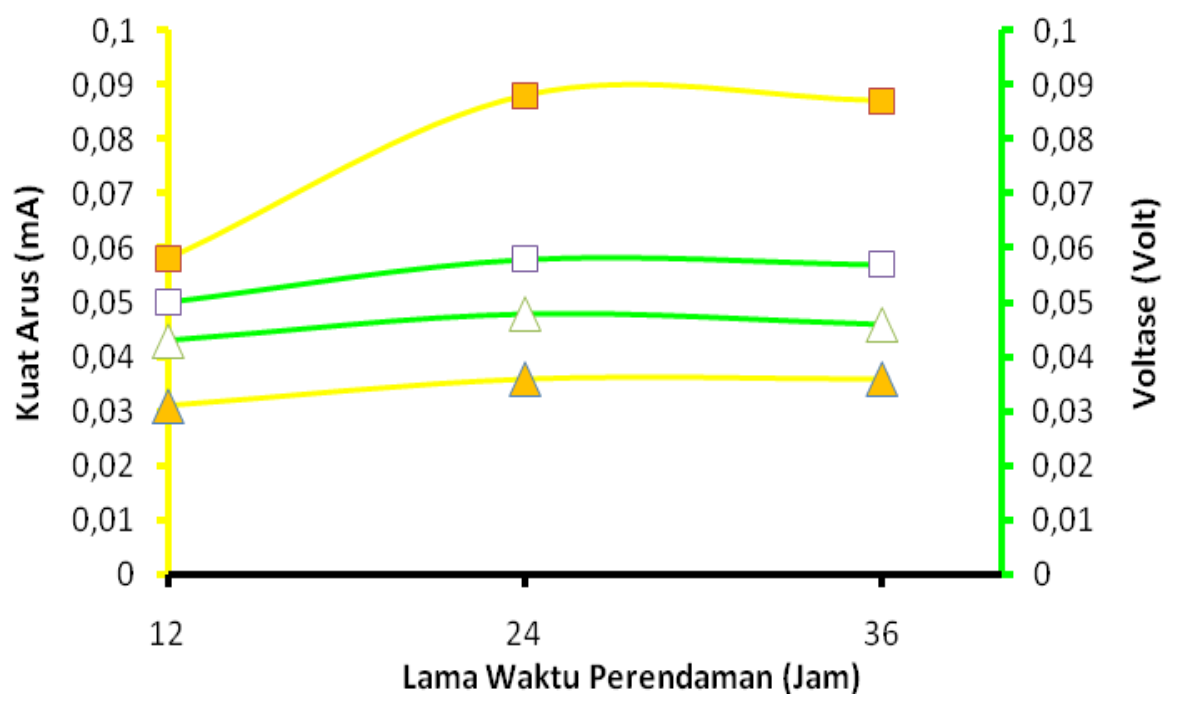

Gambar 1. Pengaruh Lama Waktu Perendaman $\mathrm{Cu}$ dengan $\mathrm{NaOH}$ Untuk Pembuatan Elektroda CuO Terhadap Kuat Arus (I) dan Voltase (V) Sel Fotovoltaik. (- $\triangle$ - I Sebelum disinari, - - - I saat disinari, $-\Delta$ - V sebelum disinari, $-\square$ - V saat disinari)

Penentuan Konsentrasi Optimum Larutan Elektrolit KCl Terhadap Kuat Arus dan Voltase yang Dihasilkan dalam Sel Fotovoltaik Pasangan Elektroda $\mathrm{CuO} / \mathrm{Cu}$ Serabut

Konsentrasi larutan elektrolit $\mathrm{KCl}$ yang digunakan dalam sel fotovoltaik sangat mempengaruhi kuat arus dan voltase yang dihasilkan. Hasil penelitian menunjukan bahwa semakin besar konsentrasi larutan elektrolit $\mathrm{KCl}$, maka semakin besar pula kuat arus yang dihasilkan. Hal ini disebabkan oleh semakin banyaknya elektron yang mengalir pada sistem fotovoltaik tersebut.

Pada Gambar 2 terlihat perbedaan kuat arus pada sel fotovoltaik sebelum penyinaran dan saat penyinaran pada waktu 5 menit. Penyinaran dengan matahari menyebabkan terjadinya peningkatan eksitasi elektron pada semikonduktor $\mathrm{CuO}$, sehingga kuat arus dan voltase yang dihasilkan lebih besar pada saat sel fotovoltaik disinari. Energi gab yang dimiliki $\mathrm{CuO}$ yaitu sekitar 1,3-1,7 eV menyebabkan semikonduktor ini sangat bagus untuk digunakan dalam sel fotovoltaik.

Pada pengukuran hari pertama, kuat arus dan voltase terus meningkat seiring dengan meningkatnya konsentrasi larutan $\mathrm{KCl}$. Larutan $\mathrm{KCl} 0,5 \mathrm{M}$ memiliki kuat arus dan voltase 
terbesar, yaitu sebesar 0,278 mA (sebelum penyinaran) dan 0,415 (saat penyinaran). Sedangkan pada penyinaran hari ke dua, kuat arus dan voltase yang dihasilkan pada konsentrasi $\mathrm{KCl} 0,5 \mathrm{M}$ mengalami penurunan. Penurunan arus yang dihasilkan dari sel fotovoltaik pasangan elektroda $\mathrm{CuO} / \mathrm{Cu}$ setelah disinari terjadi karena elektroda $\mathrm{Cu}$ telah berubah menjadi $\mathrm{CuO}$, karena teroksidasi, Fortin. et al (2002). Untuk pengukuran lebih lanjut, diambil konsentrasi 0,3 M sebagai konsentrasi optimum.

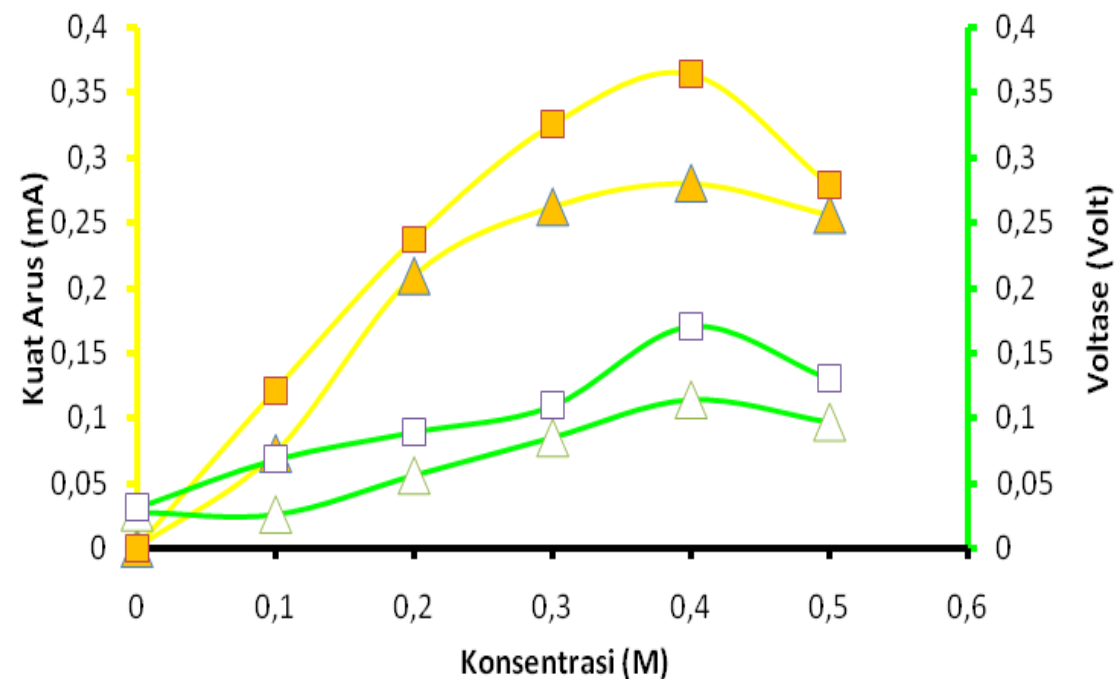

Gambar 2. Variasi konsentrasi larutan elektrolit $\mathrm{KCl}$ terhadap kuat arus (I) dan voltase (V) dari sel fotovoltaik pasangan elektroda $\mathrm{CuO} / \mathrm{Cu}$ serabut. (- $\triangle$ - I Sebelum disinari, - - - I saat disinari, $-\Delta$ - V sebelum disinari, $-\square$ - V saat disinari)

\section{Penentuan Konsentrasi Optimum Larutan Elektrolit KCl Terhadap Kuat Arus dan Voltase yang Dihasilkan dalam Sel Fotovoltaik Pasangan Elektroda $\mathrm{CuO} / \mathrm{Cu}$ Tunggal}

Kuat arus dan voltase yang dihasilkan semakin meningkat seiring dengan meningkatnya konsentrasi larutan $\mathrm{KCl}$ (Gambar 3). Pada kosentrasi 0,5 M terjadi penurunan kuat arus yang disebabkan oleh sudah mulai teroksidasinya $\mathrm{Cu}$ menjadi $\mathrm{CuO}$.

Saat disinari, kuat arus yang dihasilkan juga lebih besar dibandingkan dengan sebelum disinari. Hal ini disebabkan oleh semakin banyaknya elektron yang tereksitasi pada saat penyinaran dengan sinar matahari. Elektroda $\mathrm{CuO} / \mathrm{Cu}$ tunggal menghasilkan arus yang lebih kecil dibandingkan dengan $\mathrm{CuO} / \mathrm{Cu}$ serabut karena perbedaan luas permukaan.

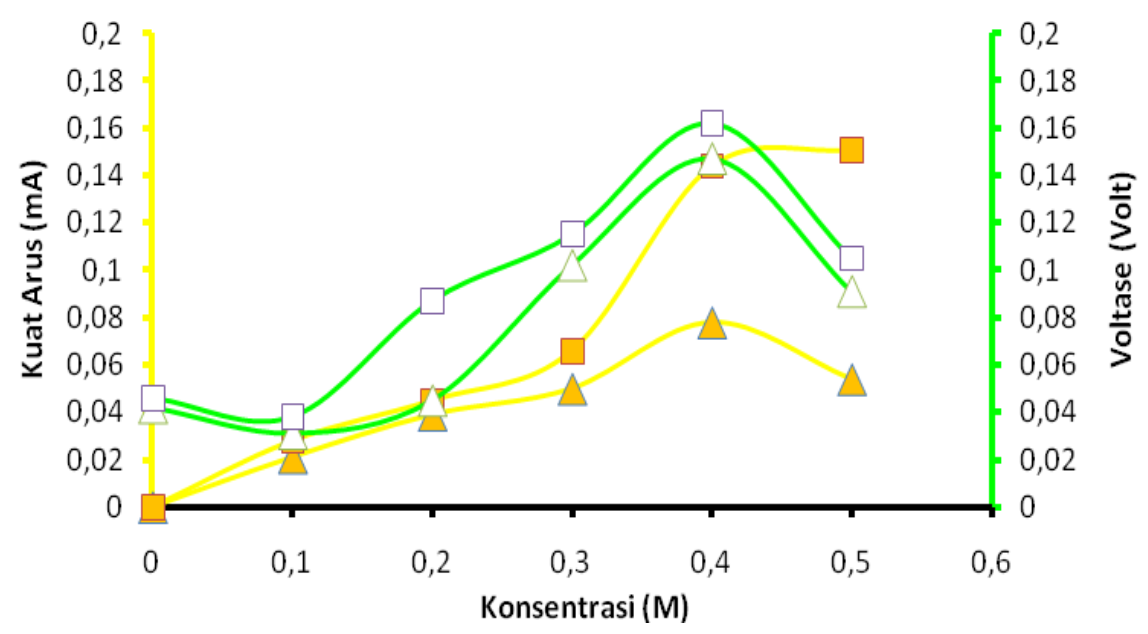

Gambar 3. Variasi konsentrasi larutan elektrolit $\mathrm{KCl}$ terhadap kuat arus (I) dan voltase (V) dari sel fotovoltaik pasangan elektroda $\mathrm{CuO} / \mathrm{Cu}$ tunggal. (- $\triangle$ - I Sebelum disinari, - - - I saat disinari, $-\Delta$ - V sebelum disinari, $-\square-\mathrm{V}$ saat disinari) 
Penentuan Konsentrasi Optimum larutan Elektrolit KCl Terhadap Kuat Arus dan Voltase yang Dihasilkan dalam Sel Fotovoltaik Pasangan Elektroda CuO Serabut / Stainless Steel

Gambar 4 menunjukkan bahwa stainless steel dapat digunakan sebagai elektroda pada sel fotovoltaik meskipun kuat arus dan voltase yang dihasilkan tidak sebesar kuat arus dan voltase yang dihasilkan oleh pasangan $\mathrm{CuO} / \mathrm{Cu}$ serabut.

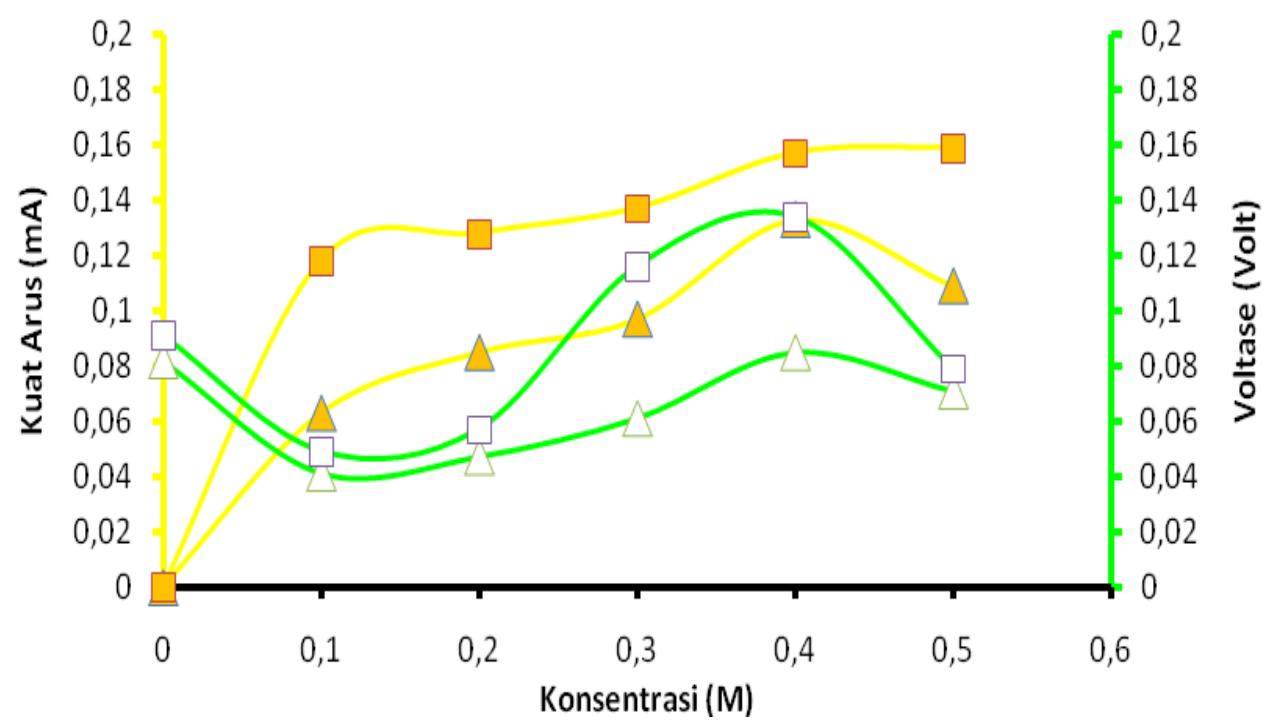

Gambar 4. Variasi konsentrasi larutan elektrolit $\mathrm{KCl}$ terhadap kuat arus (I) dan voltase (V) dari sel fotovoltaik pasangan elektroda $\mathrm{CuO}$ serabut/stainless steel.

(- $\Delta$ - I Sebelum disinari, - $\square$ - I saat disinari, - $\Delta$ - V sebelum disinari, - $\square$ - V saat disinari)

Penentuan Konsentrasi Optimum Larutan Elektrolit KCl Terhadap Kuat Arus dan Voltase yang Dihasilkan dalam Sel Fotovoltaik Pasangan Elektroda CuO Tunggal / Stainless Steel

Gambar 5 menunjukkan bahwa kuat arus yang dihasilkan pada pasangan elektroda CuO tunggal / Stainless Steel lebih kecil dari kuat arus dan voltase yang dihasilkan oleh pasangan elektroda $\mathrm{CuO}$ serabut / Stainless steel.

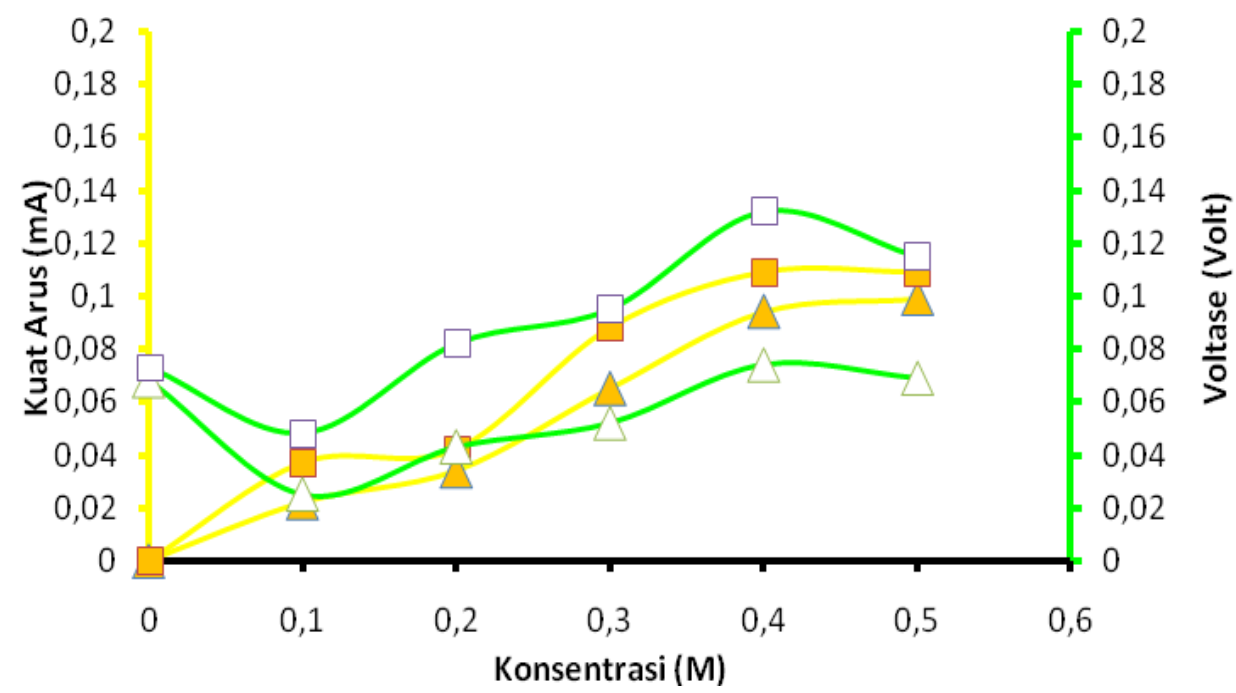

Gambar 5. Variasi konsentrasi larutan elektrolit $\mathrm{KCl}$ terhadap kuat arus (I) dan voltase (V) dari sel fotovoltaik pasangan elektroda $\mathrm{CuO}$ serabut/stainless steel.

(- $\triangle$ - I Sebelum disinari, - $\square$ - I saat disinari, $-\Delta$ - V sebelum disinari, - $\square$ - V saat disinari) 
Pengaruh Variasi Waktu (Saat Pengukuran) Terhadap Kuat Arus dan Voltase dari Sel Fotovoltaik Pasangan Elektroda CuO/Cu Serabut

Konsentrasi optimum larutan elektrolit $\mathrm{KCl}$ yang didapatkan adalah $0.3 \mathrm{M}$. Gambar 6 menunjukkan bahwa waktu (saat pengukuran) dapat mempengaruhi besarnya kuat arus dan voltase yang dihasilkan oleh suatu sel fotovoltaik. Besarnya arus yang dihasilkan juga dipengaruhi dari besarnya intensitas cahaya matahari pada waktu itu dan juga umur dari sel surya (Cahyono Putra, 2000).

Kuat arus yang terbesar terdapat pada pengukuran pada pukul 11.00 WIB yaitu sebesar 0,292 mA (sebelum disinari) dan 0,334 $\mathrm{mA}$ (saat disinari) karena intensitas cahaya matahari terbesar didapatkan pada jam 11.00 - 12.00 WIB. Hal ini menunjukkan bahwa intensitas cahaya yang digunakan oleh sel fotovoltaik sangat bergantung pada waktu (saat pengukuran).

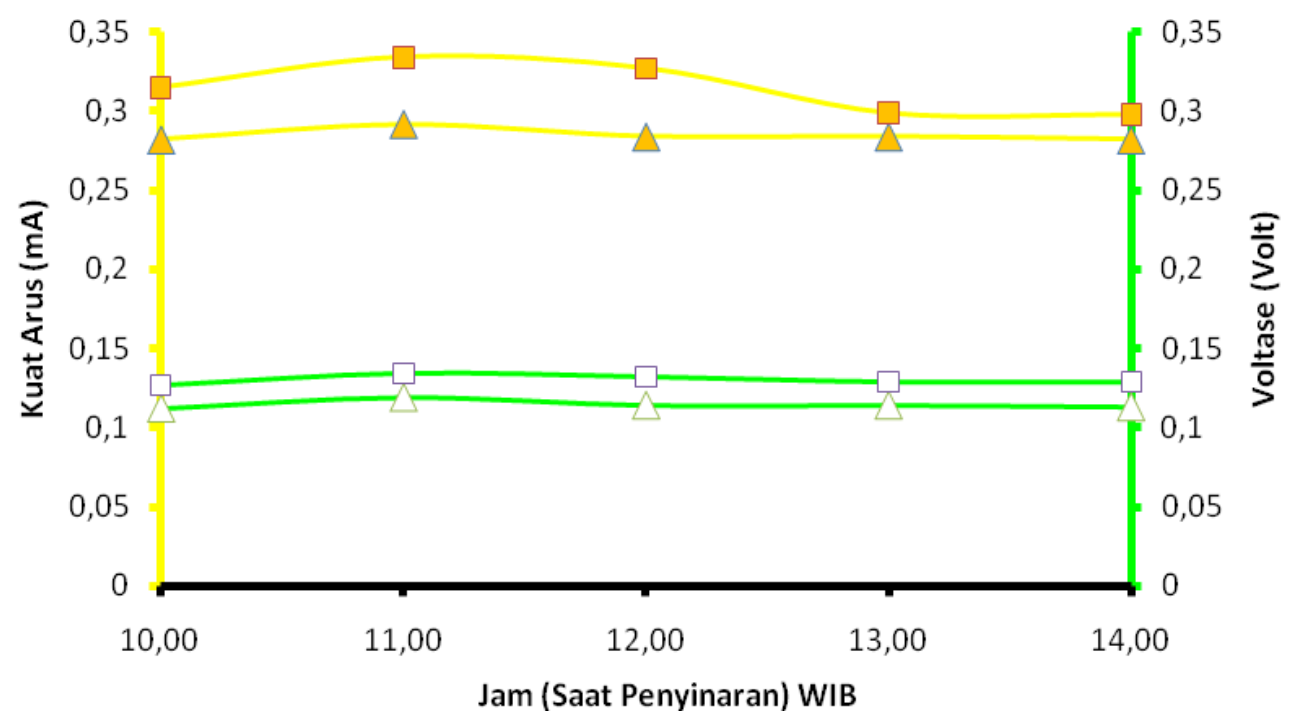

Gambar 6. Pengaruh Variasi Waktu (Saat Pengukuran) Terhadap Kuat Arus (I) dan Voltase (V) yang Dihasilkan Sel Fotovoltaik Pasangan Elektroda CuO/Cu Serabut.

(- $\Delta$ - I Sebelum disinari, - $\square$ - I saat disinari, $-\Delta$ - V sebelum disinari, - $\square$ - V saat disinari)

Pengaruh Variasi Waktu (Saat Pengukuran) Terhadap Kuat Arus dan Voltase dari Sel Fotovoltaik Pasangan Elektroda $\mathrm{CuO} / \mathrm{Cu}$ Tunggal

Kuat arus yang dihasilkan relatif konstan pada saat disinari (Gambar 7). Ini menunjukkan bahwa pasangan elektroda ini bisa dipakai dalam jangka waktu yang cukup lama dan bisa dipakai walaupun tidak pada intensitas cahaya maksimum (menjelang sore). Sedangkan pengukuran yang dilakukan sebelum penyinaran menunjukkan semakin sore maka kuat arus dan voltase yang dihasilkan semakin menurun.

Pengaruh Variasi Waktu (Saat Pengukuran) Terhadap Kuat Arus dan Voltase dari Sel Fotovoltaik Pasangan Elektroda CuO Serabut/Stainless Steel

Gambar 8 menunjukkan pengukuran kuat arus dan voltase pada pasangan elektroda CuO serabut/ Stainless Steel lebih besar pada saat penyinaran dibandingkan dengan pada saat sebelum penyinaran.

Pasangan $\mathrm{CuO}$ serabut/Stainless Steel merupakan pasangan elektroda yang cukup baik untuk digunakan pada sel fotovoltaik. Hal ini dikarenakan disamping luasnya permukaan elektroda, stainless steel juga mengandung silikon yang dapat berfungsi sebagai konduktor yang baik. 


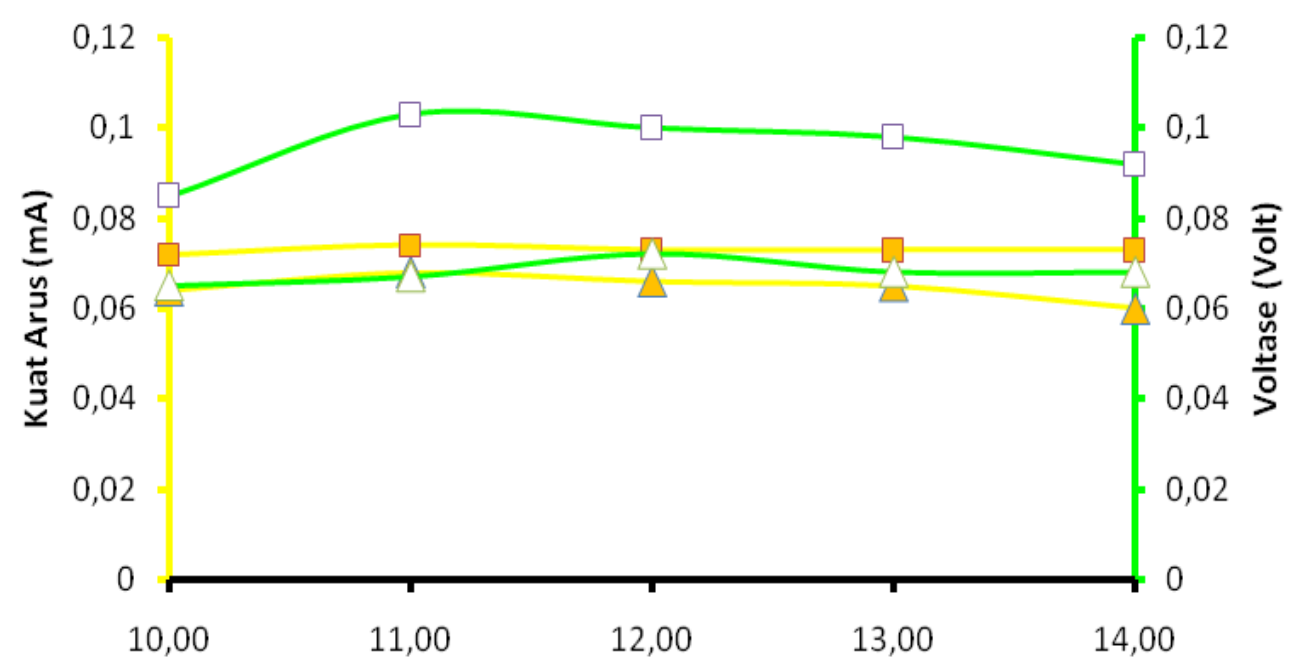

Jam (Saat Penyinaran) WIB

Gambar 7. Pengaruh Variasi Waktu (Saat Pengukuran) Terhadap Kuat Arus (I) dan Voltase (I) yang Dihasilkan Sel Fotovoltaik Pasangan Elektroda $\mathrm{CuO} / \mathrm{Cu}$ Tunggal.

(- $\triangle$ - I Sebelum disinari, - $\square$ - I saat disinari, - $\Delta$ - V sebelum disinari, - $\square$ - V saat disinari)

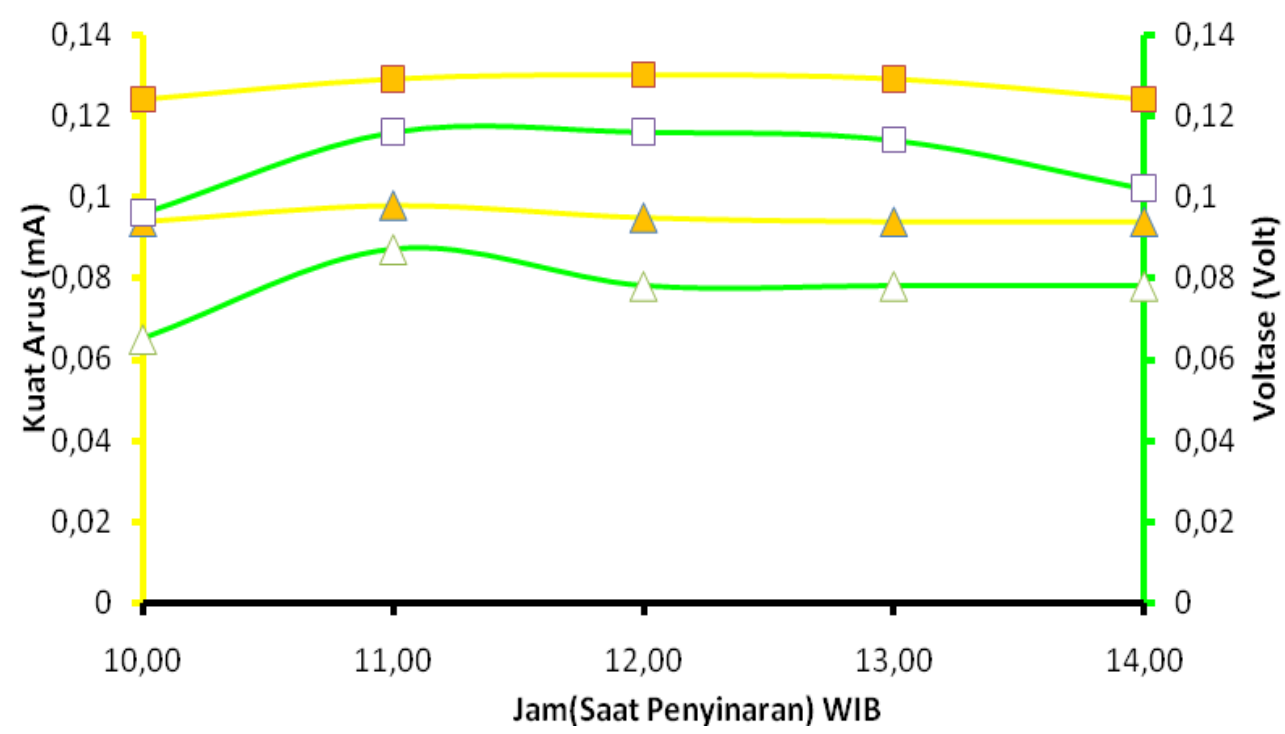

Gambar 8. Pengaruh Variasi Waktu (Saat Pengukuran) Terhadap Kuat Arus (I) dan Voltase (V) yang Dihasilkan Sel Fotovoltaik Pasangan Elektroda CuO Serabut/Stainless Steel. (- $\triangle$ - I Sebelum disinari, - - I saat disinari, $-\Delta$ - V sebelum disinari, $-\square$ - V saat disinari)

Pengaruh Variasi Waktu (Saat Pengukuran) Terhadap Kuat Arus dan Voltase dari Sel Fotovoltaik Pasangan Elektroda CuO Tunggal/Stainless Steel

Gambar 9 memperlihatkan bahwa pasangan elektroda $\mathrm{CuO}$ tunggal/Stainless Steel dapat menghasilkan kuat arus dan voltase yang dihasilkan relatif konstan, karena hanya terjadi sedikit penurunan dengan semakin lamanya waktu penyinaran. Tetapi perlakuan terhadap sel fotovoltaik menunjukkan bahwa pasangan elektroda $\mathrm{CuO}$ tunggal/Stainless Steel yang disinari menghasilkan kuat arus dan voltase yang lebih besar pada pukul 11:00. Jadi, pasangan elektroda CuO/Stainless Stell dapat digunakan sebagai semikonduktor dan konduktor pada sel fotovoltaik cair dengan menggunakan elektrolit $\mathrm{KCl}$. 


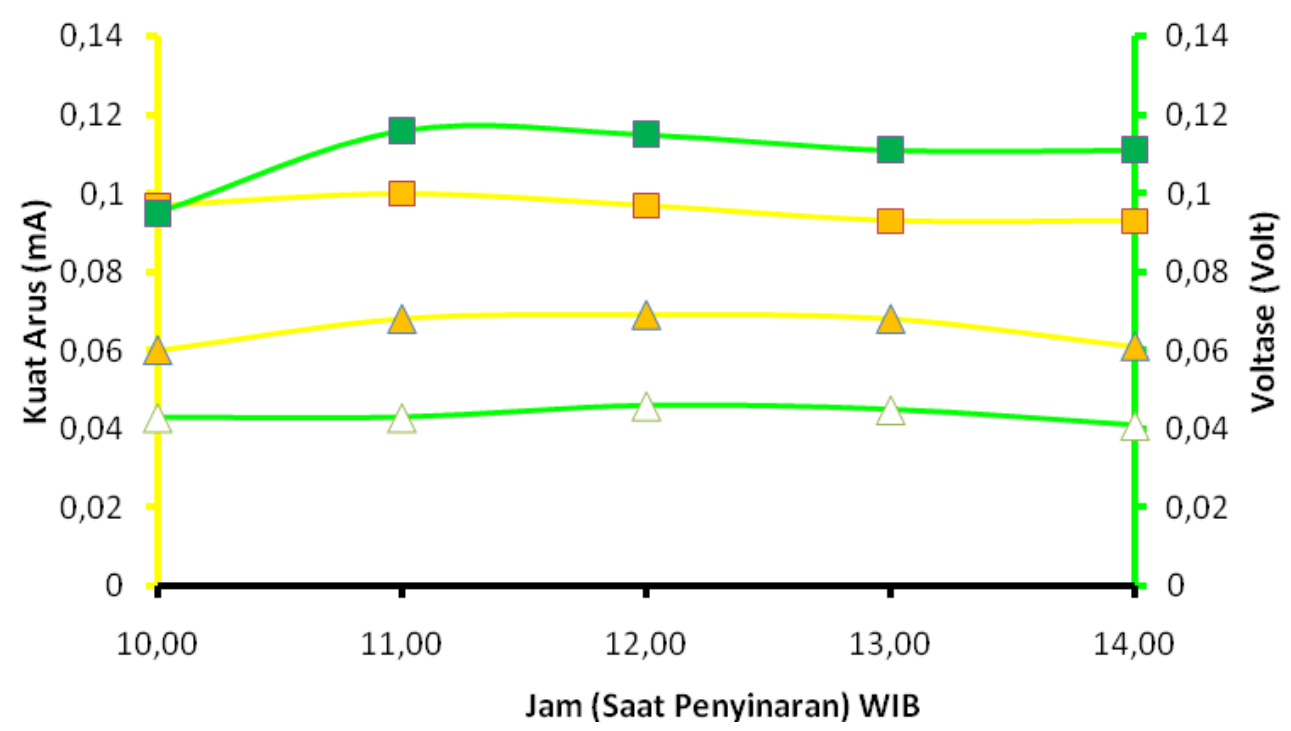

Gambar 9. Pengaruh Variasi Waktu (Saat Pengukuran) Terhadap Kuat Arus (I) dan Voltase (V) yang Dihasilkan Sel Fotovoltaik Pasangan Elektroda CuO Tunggal/Stainless Steel. (- $\Delta-$ I Sebelum disinari, - $\square$ - I saat disinari, $-\Delta$ - V sebelum disinari, - $\square$ - V saat disinari)

\section{KESIMPULAN}

Elektroda pasangan $\mathrm{CuO} / \mathrm{Cu}$ dan $\mathrm{CuO} /$ Stainless Steel dapat digunakan dalam sel fotovoltaik cair. Konsentrasi larutan elektrolit $\mathrm{KCl}$ berbanding lurus dengan kuat arus dan voltase. Semakin tinggi konsentrasi, maka kuat arus dan voltase juga semakin tinggi sampai pada batas kestabilan $\mathrm{Cu}$. Selain itu, konsentrasi larutan elektrolit yang tinggi menyebabkan $\mathrm{Cu}$ teroksidasi menjadi $\mathrm{CuO}$ (kestabilannya terganggu).

Lama waktu perendaman $\mathrm{Cu}$ untuk membuat $\mathrm{CuO}$ dengan $\mathrm{NaOH}$ 0,5 $\mathrm{N}$ mempengaruhi besar arus yang dihasilkan. Semakin lama waktu perendaman maka semakin besar arus yang dihasilkan. Tetapi dengan terlalu lamanya waktu perendaman, maka arus yang dihasilkan akan semakin turun. Kuat arus yang dihasilkan pada perendaman selama 12, 24, 36 jam adalah $0.058 \mathrm{~mA}, 0.088 \mathrm{~mA}$, $0.087 \mathrm{~mA}$.

\section{DAFTAR PUSTAKA}

1. Fortin, E and D. Masson. 2002. Photovoltaic Effects In Cu2O---Cu Solar Cells Grown By Anodic Oxidation. Department of Physics, University of Ottawa, Ottawa, Canada. Volume 25, Issue 4, Pages 281-283.

2. Sears, W.M and E. Fortin. 2003. Preparation And Properties Of $\mathrm{Cu} 2 \mathrm{O} / \mathrm{Cu}$ Photovoltaic Cells. Physics Department, University of Ottawa, Ottawa, Ontario K1N 9B4, Canada. Volume 10, Issue 1, Pages 93-103

3. McGehee, Michael D. 2006. Ordered Bulk Heterojunction Photovoltaic Cells. Materials Science and Engineering.

4. Kelly, A Nelson; Thomas L. Gibson. 2008. Solar Energy Concentrating Reactors For Hydrogen Production By Photoelectrochemical Water Spiltting. General Motors R\&D Center, Chemical and Environmental Sciences Laboratory, USA.

5. Liu, Zhaoyue, et al. 2009. Hydrogen Generation Under Sunlight By Self Ordered TiO2 Nanotube Arrays. Chemical and Metallurgical Engineering, University of Nevada, USA.

6. Sreethawong, $\mathrm{T}$ et al. 2008. Comparative Investigation Of Mesoporous and NonMesoporous Assembled TiO2 Nanocrystals For Photocatalytic H2 Prodution Over N- 
Doped TiO2 Under Visible Light Irradiation. The Petroleum and Petrochemical College, Chulalongkorn University, Thailand.

7. Safana, Sultan. Energi Panas Surya Dipanaskan. 2010.

8. Hasbullah, MT. Konversi Energi Surya. Teknik Elektro FPTK: UPI

9. Cahyono Putro, Setiadi. 2000. Upaya Peningkatan Efisiensi Sel Surya Fotovoltaik Sebagai Konvertor Cahaya Matahari Menjadi Energi Listrik. Teknologi Kejuruan, Vol 23, No. 2. 